Brit. Heart f., 1967, 29, 190.

\title{
Clinical Presentation of Myocardial Infarction in the Elderly
}

\author{
M. S. PATHY \\ From the Department of Geriatrics, St. David's Hospital, Cardiff
}

The clinical features of myocardial infarction in the elderly may be extremely variable and sometimes so unobtrusive that the diagnosis is overlooked. This study records the clinical presentation of cardiac infarction in a personal series of 387 patients, aged 65 and over, seen during a period of 11 years; 121 were aged 80 to 90 years, and 17 were over 90 . Part of this series has been described previously (Pathy, 1963).

\section{METHOD}

The patients were divided into 15 groups according to the presenting picture (see Table I). A symptom was not necessarily unique to any one group. Thus, breathlessness was a fairly common symptom in patients in several groups; a hemiplegia appeared to be related to the cardiac infarction in 3 patients in Group 2.

In all groups with the exception of Groups 2 and 4, a history of pain, discomfort, or tight or pressing sensation in the substernal or epigastric area was absent on careful questioning of the patient, and, when possible, the relatives. Clearly a negative history of pain in Group 3 patients must be taken with reserve.

Patients were excluded from the investigation where an adequate history was unobtainable due to the severity of the illness: coma without regaining consciousness, a recent stroke with severe aphasia, or severe chronic confusional states.

A diagnosis of recent cardiac infarction was based on electrocardiographic and/or pathological changes.

Electrocardiographic Changes. Recent cardiac infarction was considered to be substantiated if serial electrocardiograms satisfied the following four conditions. (1) Abnormal Q waves or QS complexes of $0.04 \mathrm{sec}$. or more in width. (2) ST segment changes: ST elevation or depression of over $2 \mathrm{~mm}$. with or without reciprocal ST change. (3) $\mathrm{T}$ wave changes: symmetrical $\mathrm{T}$ wave inversion. Patients with superimposed digitalis effect were not excluded from the series provided that the

Received December 22, 1965. changes in the electrocardiogram were otherwise unequivocally consistent with the diagnosis. (4) A significant alteration, usually in the ST segment or T wave, in at least two serial tracings.

Of the patients who survived for at least four weeks, 13 had two or three serial electrocardiograms. The remaining 208 patients had four or more tracings with an average of five. At least 12 leads were recorded. Posterior chest and third interspace leads were recorded in a few patients with equivocal electrocardiograms. In 42 patients $(12 \%$, excluding Group 4 cases), where the above criteria were either not fully satisfied or were in doubt because of left bundle-branch block, left ventricular hypertrophy, or previous ischæmic heart disease, the diagnosis was confirmed by necropsy. However, the electrocardiogram was required to be at least compatible with a recent infarction. Fifty-six patients with probable cardiac infarction, but equivocal electrocardiograms, survived longer than four weeks and were, therefore, omitted from the study. Mitchell and Schwartz (1963) noted that 14 per cent of their patients had doubtful cardiograms due to left bundle-branch block in five, and ST-T changes without abnormal Q waves in four. The latter all had large posterior lesions at necropsy.

TABLE 1

CLINICAL FEATURES OF MYOCARDIAL INFARCTION IN 387 PATIENTS AGED 65 AND OVER

\begin{tabular}{c|l|c}
\hline Group & \multicolumn{1}{|c}{ Mode of presentation } & $\begin{array}{c}\text { Number } \\
\text { of cases }\end{array}$ \\
\cline { 1 - 1 } 1 & $\begin{array}{lll}\text { Sudden dyspncea or exacerbation of heart } \\
\text { failure }\end{array}$ & 77 \\
2 & “Classical" onset & 75 \\
3 & Acute confusion & 51 \\
4 & Sudden death & 31 \\
5 & Syncopal attacks & 27 \\
6 & Strokes & 26 \\
7 & Giddiness, vertigo, or faintness & 22 \\
8 & Peripheral gangrene or increased claudication & 19 \\
9 & Palpitation & 14 \\
10 & Renal failure & 11 \\
11 & Recurrent vomiting & 10 \\
12 & Weakness & 10 \\
13 & Pulmonary embolus & 8 \\
14 & Restlessness & 4 \\
15 & Sweating & 2 \\
& &
\end{tabular}


Pathological Changes. $166(43 \%)$ patients died within four weeks of the onset of symptoms of cardiac infarction. Post-mortem examination was performed in 152 $(92 \%)$. Estimation of the age of an infarct was essentially based on the macroscopic and histological changes described by Mallory, White, and SalcedoSalgar (1939). After about the fourth week, the age of an infarct was difficult to determine with any reasonable accuracy. Old infarcts, often multiple, were commonly noted. Patients dying more than four weeks after the clinical onset of infarction were, therefore, excluded if the diagnosis depended on necropsy findings.

\section{RESULTS}

Group 1. Breathlessness was the presenting feature noted by the 77 patients in this group. Thirty-nine had been in heart failure for some time and eight of these had previous cardiac infarction. The new catastrophe was heralded by a sudden increase in the severity of the dyspnœa with a variable accentuation of other signs of heart failure. Thirteen of the 39 patients were noted to have hypertension. In the 38 cases without evidence of previous heart failure, the onset of breathlessness was sudden and usually severe and progress to acute pulmonary odema was not uncommon. Sixteen cases had hypertension. Atrial fibrillation was unexpectedly frequent, and was found in 15 not previously in heart failure and in 21 of those who had been in failure.

The incidence of sudden and sometimes catastrophic exacerbation of heart failure is probably higher than the above figures suggest. It is in this category of patient that the greatest difficulty may be experienced in interpreting the electrocardiogram. Previous infarctions, left ventricular hypertrophy due to associated hypertension, left bundle-branch block, or excessive digitalization may render the electrocardiographic diagnosis uncertain.

Group 2. Seventy-five patients presented with symptoms of constricting pressure or heavy substernal or epigastric pain, tightness or discomfort, with or without shock, vomiting, dyspnœa, or any of the symptoms noted in the other groups. A previous history of angina was noted in 19 patients, an incidence much greater than in any other group.

Group 3. An acute confusional state is a presentation common to many diseases in the elderly and cardiac infarction is no exception. The confusion follows no fixed pattern, though commonly the patient is agitated, noisy, or aggressive or he may suddenly wander about the house one night. A rapid increase in confusion in an already disturbed patient is not infrequent. Where confusion persists, necropsy may show areas of cerebral infarction, often without an obvious occlusive cerebrovascular lesion. In the 51 cases included in this category, no history or indication of chest pain or discomfort could be obtained. In the presence of confusion, this manifestly does not exclude such symptoms.

Group 4. Thirty-one patients died suddenly and unexpectedly. In each case a recent myocardial infarction was found on post-mortem examination and was considered to be the immediate cause of death.

Group 5. One or more episodes of sudden loss of consciousness lasting for five to thirty minutes characterized the illness in 27 patients. All denied chest pain or discomfort on regaining consciousness and none could recall pain before loss of consciousness. Six of the patients had atrial fibrillation, one had ventricular tachycardia, and only one had heart block (rate 42 a minute). Frequent faints lasting for about a minute or less are not uncommon in the elderly who have hypotension following cardiac infarction. These are usually accompanied by other symptoms and such patients were not included in this group.

Group 6. A hemiplegia was the presenting clinical problem in 26 patients. Atrial fibrillation was noted in 7 patients. The causes of the strokes, where they could be ascertained, were as follows: (1) Cerebral infarction without post-mortem evidence of an occlusive lesion of the intracranial or extracranial arteries of the brain; widespread atherosclerosis was usually present and infarction was possibly due to a fall in systemic blood pressure resulting in a critical reduction of cerebral blood flow; (2) thrombotic occlusion of an intracranial or extracranial artery in the brain; or (3) embolic cerebral arterial occlusion.

Group 7. Sensations of giddiness, vertigo, or faintness are common in cardiac infarction, but were the dominating symptoms in 22 patients.

Group 8. Seventeen of the 19 patients in this group presented with symptoms due to sudden occlusion of one or more peripheral arteries. The remaining two were seen as a result of a dramatic increase in intermittent claudication followed within 24 hours by continuous pain in the leg at rest. Ten other patients developed arterial occlusive incidents between 5 and 12 days after initial symptoms, such as chest pain, dyspnœa, or confusion, and are included 
TABLE II

OCCLUSIVE ARTERIAL INCIDENTS IN 17 PATIENTS

\begin{tabular}{|c|c|c|c|c|c|}
\hline Sex & $\begin{array}{l}\text { Site of arterial } \\
\text { occlusion }\end{array}$ & $\begin{array}{l}\text { Result of arterial } \\
\text { occlusion }\end{array}$ & $\begin{array}{l}\text { Complicating } \\
\text { conditions }\end{array}$ & Specific treatment & Result \\
\hline $\begin{array}{l}\mathbf{F} \\
\mathbf{F}\end{array}$ & $\begin{array}{l}\text { Axillary artery } \\
\text { Axillary artery }\end{array}$ & $\begin{array}{l}\text { Gangrene of upper limb } \\
\text { Gangrene of forearm and }\end{array}$ & Diabetes & $\begin{array}{l}\text { Anticoagulants } \\
\text { Anticoagulants; }\end{array}$ & $\begin{array}{l}\text { Died } \\
\text { Recovered }\end{array}$ \\
\hline $\mathbf{F}$ & $\begin{array}{l}\text { Brachial artery } \\
\text { bifurcation ( ?) }\end{array}$ & $\begin{array}{l}\text { hand } \\
\text { Ischæmic changes in } \\
\text { hand and fingers }\end{array}$ & - & $\begin{array}{l}\text { amputation } \\
\text { Anticoagulants }\end{array}$ & $\begin{array}{l}\text { Recovered, loss of top } \\
\text { of one finger }\end{array}$ \\
\hline $\mathbf{F}$ & $\begin{array}{l}\text { (i) Left axillary } \\
\text { artery } \\
\text { (ii) Bifurcation right } \\
\text { brachial artery } \\
\text { (iii) Popliteal artery }\end{array}$ & $\begin{array}{l}\text { Gangrene of left upper } \\
\operatorname{limb} \text {, right hand, right } \\
\text { leg }\end{array}$ & 一 & Anticoagulants & $\begin{array}{l}\text { Died of renal failure; } \\
\text { renal emboli at } \\
\text { necropsy }\end{array}$ \\
\hline $\mathbf{F}$ & $\begin{array}{l}\text { Brachial artery; saddle } \\
\text { embolus of aorta }\end{array}$ & $\begin{array}{l}\text { Ischæmic change in right } \\
\text { forearm and both } \\
\text { lower limbs }\end{array}$ & - & Anticoagulants & Died \\
\hline $\mathbf{F}$ & $\begin{array}{l}\text { Brachial, both popliteal } \\
\text { arteries; cerebral } \\
\text { embolus }\end{array}$ & $\begin{array}{l}\text { Ischæmic changes in left } \\
\text { hand and leg; gan- } \\
\text { grene of right leg }\end{array}$ & Diabetes & $\begin{array}{l}\text { Anticoagulants; } \\
\text { amputation right } \\
\text { leg }\end{array}$ & Good recovery \\
\hline $\mathbf{F}$ & $\begin{array}{c}\text { Popliteal and middle } \\
\text { cerebral arteries }\end{array}$ & Gangrene of leg & Diabetes & Amputation & Died \\
\hline $\mathbf{M}$ & $\begin{array}{l}\text { Bifurcation of common } \\
\text { iliac }\end{array}$ & Gangrene of lower limb & 一 & Anticoagulants & $\begin{array}{l}\text { Died, embolus superior } \\
\text { mesenteric artery at } \\
\text { necropsy }\end{array}$ \\
\hline $\mathbf{M}$ & Popliteal artery & Gangrene of leg & $\begin{array}{l}\text { Diabetes and chronic } \\
\text { peripheral arterial } \\
\text { disease }\end{array}$ & Anticoagulants & Died \\
\hline $\mathrm{F}$ & Popliteal artery & Gangrene of leg & $\begin{array}{l}\text { Chroase } \\
\text { arterial disease }\end{array}$ & Anticogulants; & Recovered \\
\hline $\begin{array}{l}\mathbf{M} \\
\mathbf{M}\end{array}$ & $\begin{array}{l}\text { Iliac artery } \\
\text { Femoral artery }\end{array}$ & $\begin{array}{l}\text { Gangrene of leg } \\
\text { Gangrene of leg }\end{array}$ & - & $\begin{array}{l}\text { Amputation } \\
\text { Anticoagulants; } \\
\text { amputation }\end{array}$ & $\begin{array}{l}\text { Recovered } \\
\text { Recovered }\end{array}$ \\
\hline M & Popliteal artery & Gangrene of toes & $\begin{array}{l}\text { Diabetes and chronic } \\
\text { peripheral arterial } \\
\text { disease }\end{array}$ & $\begin{array}{l}\text { Above knee } \\
\text { amputation }\end{array}$ & Died \\
\hline M & Femoral artery & $\begin{array}{l}\text { Gangrene of dorsum of } \\
\text { foot }\end{array}$ & $\begin{array}{l}\text { Diabetes; chronic peri- } \\
\text { pheral arterial disease }\end{array}$ & $\begin{array}{l}\text { Below knee amputation; } \\
\text { re-amputation above } \\
\text { knee three months } \\
\text { later }\end{array}$ & Recovered \\
\hline M & Popliteal artery & Gangrene of toes & Chronic peripheral & Local amputation & Recovered \\
\hline $\mathbf{M}$ & Popliteal artery & $\begin{array}{l}\text { Ischæmic changes in } \\
\text { foot, gangrene of toe }\end{array}$ & $\begin{array}{l}\text { Chronic peripheral } \\
\text { arterial disease }\end{array}$ & & $\begin{array}{l}\text { Recovered; affected toe } \\
\text { separated naturally }\end{array}$ \\
\hline $\mathbf{M}$ & Posterior tibial artery & Gangrene of toes & $\begin{array}{l}\text { Chronic peripheral } \\
\text { arterial disease }\end{array}$ & Anticoagulants & Died \\
\hline
\end{tabular}

under the group appropriate to the presenting symptoms.

Data relating to 17 cases in this group are given in Table II. Angiography was not performed, and in those who survived, or where the limb arteries were not examined fully at necropsy, the site of obstruction was based on clinical findings. Where only a single obstructive lesion occurs, it may be difficult to distinguish embolism from thrombosis.

Atrial fibrillation was present in five of these patients. All those with ischæmic involvement of the upper limb were women. There was no obvious explanation for the sex difference. Seven patients had a history suggesting long-standing peripheral arterial disease. The two men who developed a sudden exacerbation of claudication and onset of pain in the leg at rest had respectively a nine-month and three-year history of ischæmic limb pain on exercise, but in one the pain occurred in the previously symptom-free limb. In both cases the symptoms improved slowly over a period of three months.

Group 9. Palpitation due to cardiac arrhythmia is common with cardiac infarction, but other symptoms usually dominate the picture. In 14 patients, palpitation was the presenting symptom and was due to atrial fibrillation in eight, atrial tachycardia in four, ventricular tachycardia in one, and multiple ectopic beats in one. Ventricular tachycardia was a symptom causing anxiety in two patients, but marked dyspnœa with heart failure was the presenting complaint, and they were, therefore, included in Group 1.

Group 10. Progressive renal failure with azotæmia may give rise to difficulty in diagnosis. The rapid onset of progressive lethargy, lassitude, asthenia, and anorexia, associated with a rising blood urea, marked the early stages of the illness in 11 patients. In only one patient was marked hypotension a notable feature. Blood urea estimations ranged from 190 to $400 \mathrm{mg}$. per $100 \mathrm{ml}$. (based on the highest figure recorded for each patient). Of the eight patients who died, two had postmortem evidence of renal emboli which were not thought, however, to have significantly contributed to the renal failure. One of these two also had 
cerebral infarction which had not been clinically recognized during life.

Group 11. Vomiting has long been recognized as a frequent accompaniment of cardiac infarction. Severe recurrent vomiting was the dominating symptom in 10 patients. In one man it persisted for six days. Patients who were taking digitalis in any form were excluded from this group.

Group 12. Weakness, often intense and distressing, was the main complaint in 10 patients in this group. Though there was evidence that the blood pressure had fallen in 3 patients, in none was hypotension a feature.

Group 13. Eight patients presented clinically with pulmonary embolization: seven subsequently died within 12 hours to seven days after the onset of symptoms. Cardiac infarction was strongly suspected on electrocardiographic evidence in three of them. At necropsy all had evidence of one or more pulmonary emboli and recent cardiac infarction: the source of the pulmonary emboli was the lower limb veins in three, a right mural intraventricular septal thrombus in one, and a right atrial mural thrombus in two patients; the source of the embolus could not be found in one. The patient who recovered presented with pain in the left posterior aspect of the chest and increasing shortness of breath for three days. She was found to have a large, heavily blood-stained pleural effusion and evidence of a venous thrombosis in the left leg. An electrocardiographic record was typical of anterior infarction. Subsequent tracings were consistent with this diagnosis. About six hours after admission to hospital the patient complained of severe pain in the right chest on inspiration. No abnormal signs were detected, but a possible pulmonary embolism was diagnosed. The patient made an uneventful recovery, the left pleural effusion clearing entirely in about seven weeks. It was felt that the effusion, though large, was secondary to pulmonary infarction.

Group 14. Like many of the symptoms to which reference has been made, restlessness is common in cardiac infarction. In four patients it was the presenting symptom. Restlessness suddenly developed in one patient while in hospital for treatment of a gastric ulcer. The four patients were acutely aware of the restlessness and were very apprehensive. They admitted to no other symptoms and were unable to give any explanation for their restlessness. This symptom lasted from two to four days.
Group 15. Profuse sweating appears to be a less frequent symptom in the elderly than in the young. As an isolated symptom in cardiac infarction it is unlikely to be investigated owing to its evanescence and apparent insignificance. The first patient was awakened in the early hours of the morning by intense perspiration. The second patient also developed marked sweating while in bed, though she could not give the time of onset accurately. Because of associated tachycardia, her family doctor suspected thyrotoxicosis. This was not confirmed. Serial cardiograms showed a posterior myocardial infarction in both patients.

\section{Discussion}

Infarction of the myocardium may produce few or no symptoms and only be discovered at necropsy. Barnes and Ball (1932) found myocardial infarction in 49 of a series of 1000 consecutive necropsies. Gould and Cawley (1958) reviewed 5000 consecutive necropsies and noted one or more healed cardiac infarcts in $175(3.5 \%)$ of them. In a study of 500 old people, aged 70-99, in a nursing home, Fisch et al. (1957) noted electrocardiographic changes diagnostic of old cardiac infarction in 12 patients but no criteria were given for the changes that they considered diagnostic. It is our experience that an unequivocal diagnosis of an old cardiac infarction on electrocardiographic evidence alone is extremely difficult in the aged.

Since Hammer (1878) clinically diagnosed myocardial infarction, pain behind the sternum with characteristic qualities and radiation of variable extent has for long been accepted as a cardinal symptom of infarction of the myocardium. Whereas the concomitant symptoms are, for the most part, well recognized, their ability to dominate the clinical picture is less fully appreciated.

It is now generally conceded that chest pain may be absent in cardiac infarction. Angina pectoris sine dolore was the term used by Gairdner (1891) for cases of painless coronary heart disease. Gallavardin (1921) drew attention to the fact that some patients may die of infarction without complaining of pain. East, Bain, and Cary (1928) also pointed out that infarction might be painless. Since these early papers, there have been over 30 reports of cases of painless infarction.

The recorded incidence of pain-free infarction has varied widely due to differences of interpretation of the term painless infarction, and in the majority of reports it has closely paralleled the frequency of severe dyspnœa. Parkinson and Bedford (1928) noted that two patients $(2 \%)$ in their series, the only 
two presenting with severe dyspnœa, gave no history of pain. Levine and Brown (1929) found 48 per cent without pain, Davis (1932) 38 per cent, Howard (1934) 6 per cent, Saphir et al. (1935) 38 per cent, Bruenn, Turner, and Levy (1936) 39 per cent, and Boyd and Werblow (1937) 33 per cent. Kennedy (1937) accepted four (4\%) of his 94 patients as being truly pain-free; of the original 142 patients, he excluded 19 because of sudden death, three because of confusion, and five because of uræmia. Master, Dack, and Jaffe (1938) reported that 54 per cent of patients with post-operative coronary occlusion had no symptoms of pain, Bean (1938) noted 28 per cent, Gorham and Martin (1938) 40 per cent, and Babey (1939) 1 per cent. Dyspnœa was the commonest presenting feature in Pollard and Harvill's (1940) pain-free group (8\%). It is interesting to note that these authors make no mention of acute exacerbation of existing heart failure, a common presenting issue (Gilchrist, 1951); Gross and Engelberg (1940) noted 25 per cent without pain; Fagin and Chapnick (1950) noted 16 per cent, Warner (1951) nil, Roseman (1954) 5 per cent, Gertler et al. (1954) 2 per cent, in young adults; and Snow et al. (1956) 36 per cent. The criteria for labelling an infarct "painless" have been variable. Thus, of Gorham and Martin's 100 cases, those with vague discomfort, pressure, or a sense of constriction were included in the group classified as pain-free. Evans and Sutton (1956), in a carefully evaluated series of 70 patients, excluded all patients with an ache, tightness, or sense of pressure, indigestion, or discomfort as well as frank pain in the chest.

The incidence of painless infarction is higher in this study than in any previously described. Excluding Group 4 cases, where a history of pain was not available, due to sudden death, 73 per cent of patients denied the presence of chest pain. The relation of confusion to painless infarction has received little mention in the past. Exclusion of this group would give a 60 per cent incidence of painless infarction. It appears that the number of patients with uncommonly recognized presentations, and especially the frequency of severe dyspnœa, is in part responsible for the preponderance of painfree cases in this series.

The factors determining absence of cardiac pain have been the subject of considerable speculation. Libman (1919), Keefer and Resnik (1928), and Carr (1935) suggested hyposensitivity to pain as a possible cause. In his original paper, Herrick (1912) thought that gradual arteriosclerotic narrowing might be a factor in reducing symptoms. Hamman (1926) put forward the same view and suggested that sudden thrombotic occlusion always produces pain. However, Levine and Brown, in a study of 45 patients with necropsies, pointed out that sudden coronary occlusion may occur without pain. Wearn (1923) and Hamman (1934) noted that pain might be absent when cardiac infarction occurred in a patient with pre-existing heart failure. In 1931 Herrick postulated that involvement of "silent areas" of myocardium might give rise to painless infarction. Hay (1933) suggested that pain might be absent in patients who had had previous coronary occlusion. Snow et al. point out that the picture of painless cardiac infarction may be due to a degree of ischæmia which, though insufficient to produce pain, may, if it persists long enough, lead to infarction. Evans and Sutton stress the importance of dyspnœea, hypertension, and changes of cardiac rhythm as factors influencing absence of pain.

The sudden onset or exacerbation of dyspnœa was the commonest presenting symptom in this study. In those in whom heart failure was already present, a sudden worsening of the symptoms of failure drew attention to the ischæmic incident.

Obrastzow and Straschesko (1910) emphasized three groups of symptoms in coronary occlusion; status dysnepticus was the appellation of the group in which dyspnœa was paramount. Dyspnœa may dominate the clinical scene, and where there is preexisting heart failure, a sudden exacerbation of the signs of failure may be the only evidence of infarction (Parkinson and Bedford, 1928). Boyd and Werblow (1937) commented that the syndrome of painless coronary thrombosis was represented most commonly by unexplained dyspnœa occurring during the course of congestive cardiac failure. Bedford and Simpson (1939), Lewis (1946), Herrman (1952), Papp (1952), Roseman (1954), Friedberg (1956), Evans and Sutton (1956), and Ebert (1965) noted that pain might be overshadowed by intense dyspnœa. Gilchrist, in a masterly paper, has gone so far as to say, "Every attack of cardiac asthma should be regarded as a product of a myocardial infarct unless other demonstrable cause exists". Rose and Wilson (1959) discussed 50 consecutive necropsies in patients aged 70 and over who had had heart failure in life, for which no adequate clinical cause could be found. Pathological evidence of cardiac infarction or ischæmic fibrosis was present in 36 per cent. Pomerance (1965) examined the hearts of 370 patients, aged 75 and over, dying in a large general hospital. She found evidence of ischæmic heart disease in 48 per cent of patients with heart failure and in 18 per cent of the non-failure group. Much of the dif- 
ference was due to recent infarction which was present in 23 per cent of those in failure and in only one $(0.5 \%)$ of the others. Evans and Sutton (1956) record that seven of their patients had dyspnoea which was severe in three. All had hypertension which the authors considered might have accounted for the absence of pain. Of the 77 patients in Group 1, we found that 29 had evidence of hypertension. There was no clear evidence that hypertension played any part in preventing the onset of pain in this group.

While patients presenting with substernal or epigastric pain, discomfort, or constriction make up the second largest group, they form only 19 per cent of the total. It may be argued that the aged may misinterpret or forget symptoms and that a larger number of patients had pain, but that it was rapidly masked by other symptoms or forgotten. This, of course, may be true, but if no history of pain is forthcoming, a diagnosis must be entertained on the symptoms proffered by the patient. Of patients with a "classical onset" of infarction, 25 per cent had a past history of angina, an incidence greater than in any other group. Achor et al. (1956) reported that 53 per cent of patients dying of cardiac causes had a history of angina.

In the elderly an acute confusional state is a symptom common to many diseases and is widely appreciated as being associated with infection, cerebral infarction, myxœdema, and drug intoxication. The frequency with which cardiac infarction may initiate acute confusion has, however, received sparse recognition. Rodstein (1956) attributed the confusion to cerebral anoxia. There are no particular distinguishing features about the confusional state to indicate causation. Some of the patients in Group 3 had been mildly confused for some time. The onset of cardiac infarction produced an abrupt and marked increase of mental disturbance. Serial electrocardiography is essential where the aetiology of acute confusion is in doubt.

In An Inquiry into the Symptoms and Causes of the Syncope Anginosa Commonly Called Angina Pectoris, Caleb Parry (1799), opined that there was a causal relation between sudden death and occlusion of the coronary arteries. Because his friend, John Hunter, suffered from angina pectoris, Parry delayed publishing his little book until after Hunter's death. Leyden (1884) noted that occlusion of the coronary arteries might lead to sudden death in those in apparent perfect health.

Sudden death was the only feature of coronary occlusion in 8 per cent of patients in this study. The diagnosis was made at necropsy. It is of interest that 14 of 31 patients were standing or walking in the ward up to the time of death.

Severe chest pain rapidly followed by a syncopal episode is not uncommon with cardiac infarction (Garland and Phillips, 1953). Usually the episode of pain is recalled or still present on regaining consciousness, but not always. Boyd and Werblow recorded that a man of 55 had a sudden episode of unconsciousness due to myocardial infarction and on regaining consciousness had no chest pain. These authors commented that they had seen several similar cases. Pollard and Harvill (1940) and Cookson (1942) gave examples of cardiac infarction with a syncopal onset and noted the absence of pain on regaining consciousness. Gilchrist noted syncope to be among the many presenting symptoms of cardiac infarction. Myocardial infarction may complicate syncope due to the carotid-sinus syndrome (Heron, Anderson, and Noble, 1965).

In our 27 patients sudden loss of consciousness lasting from 5 to 30 minutes formed the clinical picture. There was no history of chest pain before or after the episodes of unconsciousness. The causes of loss of consciousness may be many. Transient heart block, reflex bradycardia, sudden rapid ventricular rate, or hypotension are possible factors, though none of these was consistently found at the time of examination. Wood (1956) suggested that "loss of consciousness may prevent appreciation of pain".

In 1928 Parkinson and Bedford drew attention to the coexistence of cerebrovascular accidents with silent myocardial infarction. Levine (1929) suggested that some cases of sudden hemiplegia may be due to a cerebral embolus secondary to a silent cardiac infarction. Subsequent studies have confirmed that the symptoms and signs of a stroke may overshadow the attending myocardial infarction (Bean and Read, 1942; Race and Lisa, 1945; Fisher and Zukerman, 1946; Bean, Flamm, and Sapadin 1949; Rogers, 1955; Evans and Sutton, 1956; Gupta, Bawa, and Wahi, 1965; Heron and Anderson, 1965). Conner and Holt (1930), in reviewing 287 patients with coronary thrombosis, stated that 14 had cerebral embolism. Meakins and Eakin (1932) reported the necropsy findings of 62 patients with coronary occlusion and noted that 4 $(6.4 \%)$ had a cerebral thrombosis. In a study of the relation between cerebral lesions and coronary thrombosis, Dozzi (1937) reviewed 1000 consecutive necropsies; 41 had myocardial infarction and 12 of these $(29 \%)$ were associated with a cerebral embolus or thrombosis. The electrocardiographic evidence of cardiac infarction and ischæmia has 
been reported in 15 per cent of patients with transient cerebral ischæmic attacks and in 30 per cent with "clinical strokes" (Acheson and Hutchinson, 1964).

It has been suggested that the incidence of cerebral emboli from mitral stenosis is falling and that at present cardiac infarction is as important a cause as rheumatic mitral stenosis (Carter, 1964). Sixty-four per cent of all arterial emboli from cardiac infarction involve arteries of the brain (Wright, Marple, and Beck, 1954). A total of 32 of our patients had a stroke which was accepted as being related to the cardiac infarction. In 26 of these the stroke was the only overt feature of the illness.

If cerebrovascular disease is present, a drop in blood pressure following cardiac infarction might result in a stroke (Stürup, 1952; Rogers, 1955). Conversely, the possibility must be entertained that, in the presence of coronary artery disease, cardiac infarction could be subsequent to hypotension due to the stroke (Bean et al., 1949; Wilson et al., 1951). Of the six patients with strokes who had other presenting symptoms and who were not included in Group 6, one had severe dyspnoea, three had chest pain, and two had embolic occlusion of limb arteries.

As in all groups in this series, the diagnosis was confirmed by serial electrocardiograms in those patients who survived. It has been shown that intracranial bleeding and cerebral infarction may produce changes in the electrocardiogram which may at times simulate cardiac infarction in the absence of post-mortem evidence of heart disease. Byer, Ashman, and Toth (1947) noted that there might be abnormalities in the $T$ waves in the cardiogram in intracranial hæmorrhage. Burch, Meyers, and Abildskov (1954) described the cardiographic pattern in cases of cerebrovascular accidents without heart disease. Wasserman et al. (1956) described changes which they ascribed to cerebrovascular accidents, but many of their patients had, in addition, clinical evidence of heart disease. Of 69 patients in the series described by Fentz and Gormsen (1962), 11 (16\%) had abnormal cardiograms, in the absence of evidence of heart disease. Menon (1964) described a woman with a cerebral hæmorrhage whose cardiogram simulated a myocardial infarction. At necropsy the heart was found to be normal. A probable cerebral venous thrombosis occurring during the puerperium in a 17-yearold girl whose electrocardiogram resembled severe ischæmic heart disease has been reported (Harrison and Gibb, 1964). Several references to abnormal electrocardiographic changes in subarachnoid hæmorrhage are on record (Levine, 1953; Shuster,
1960; Cropp and Manning, 1960; Koskelo, Punsar, and Sipilä 1964; Srivastava and Robson, 1964). These observations of changes in the cardiogram with brain damage may be held to question the validity of electrocardiographic evidence of cardiac infarction in some of the Group 6 cases. While the possibility of error cannot be disputed, none of the cardiographic tracings resembled the description of the cardiographic changes in cerebrovascular accidents observed by Burch et al. (1954).

Systematic embolic episodes have long been recognized as a complication of cardiac infarction. The emboli usually originate from left ventricular mural thrombi, though a mural thrombus is by no means always found at necropsy, possibly because it has been completely detached from the ventricular wall and rejected into the circulation (Wood, 1956). Lewis and Pickering (1934) described 2 elderly patients with symmetrical gangrene. Dissection of the palmar arches showed numerous thrombi extending into the digital arteries. Hellerstein and Martin (1947) gave the incidence of emboli in peripheral arteries as 5.5 per cent. Wood stated that "systemic embolism is detected in $5-10 \%$ of cases clinically, the majority of them cerebral". Discussing the types of heart disease giving rise to embolic incidents in the limbs, Jacobs (1959), in an excellent monograph, recorded that 9 of 122 embolic episodes involving the limbs were due to myocardial infarction. Only about one-fifth of the embolic incidents in Jacobs' cases involved an upper limb. In a study of 100 cases of sudden arterial occlusion of a limb artery, Allen, Barker, and Hines (1962) noted that disease of the coronary arteries was present in 21 cases, of which 20 had previous symptoms of peripheral arterial disease. Four of Bean's (1937) 300 cases of cardiac infarction were admitted to hospital with arteriosclerotic gangrene.

In 19 patients (Group 7) ischæmic change in one or more limbs or in the fingers or toes was the presenting issue. In 6 female patients (35\%), the upper limbs were involved: 31 per cent had diabetes and 37 per cent had evidence of peripheral arteriosclerotic disease.

Palpitation was the symptom for which medical advice was sought in 14 patients (3.6\%) in Group 9. The lower average age of Evans and Sutton's cases (59 years) may possibly account for the 30 per cent incidence of cardiac arrhythmia in their patients.

Studies of renal function in old age show a decrease in glomerular filtration (Shock, 1946, 1952; Olbrich et al., 1950) and tubular activity (Miller, McDonald, and Shock, 1952; Olbrich et al., 1950). There is a strong suggestive evidence of a progres- 
sive reduction of functioning nephrons in old age. Kidney function is adequate for normal activities in the healthy elderly, but clinical experience indicates that it may not be so when it is subjected to stress. Eleven patients in Group 10 had evidence of disturbed renal function. In only one patient was hypotension noted at the time of examination. A reduction in renal blood flow is a possible explanation for the renal failure in this group. In a study of 142 patients with cardiac infarction, Kennedy (1937) records that five had uræmia.

Pollard and Harvill (1940) and Evans and Sutton (1956) observed that sudden vomiting might be the cardinal symptom in cardiac infarction. Repeated vomiting was the presenting manifestation of infarction in the 10 patients of Group 11.

Herrick (1912) noticed marked weakness to be a symptom of coronary occlusion. Boyd and Werblow (1937) mentioned it as a presenting symptom in one of their patients. General weakness is particularly seen in old patients (White, 1951). Great weakness is often very striking even when there are but few other symptoms (Levine, 1958). Weakness was the complaint that brought 10 patients in this study under observation. The sense of weakness, limpness, and exhaustion lasted for up to six weeks and tended to fluctuate in intensity. Associated with the weakness was apparent muscle hypotonia which in some cases was so striking as to give rise to a "rag doll" state.

Eight patients in Group 13 had pulmonary embolism associated with otherwise symptomless myocardial infarction. In a series of 200 fatal cases of coronary thrombosis reported by Eppinger and Kennedy (1938), pulmonary embolism was directly responsible for death in 6.5 per cent. Evans (1964) suggests that a pulmonary embolus occurs in 15 per cent of all cases of cardiac infarction that survive long enough to be admitted to hospital. The source of the embolus is commonly the veins of the lower limbs, though in nine instances of pulmonary infarction described by Saphir et al. (1935), seven resulted from emboli from right atrial mural thrombi.

Leyden (1884) recorded restlessness as a symptom of coronary occlusion. Bean (1938) noted that restlessness was present in 44 per cent of his patients with myocardial infarction, though in none was it noted as the sole or even predominant symptom. In four of our patients restlessness was the presenting issue.

Sweating is quoted as a common symptom in cardiac infarction. Bean found it to be present in 60 per cent of his series. It may be one of the predominant complaints (Logue and Hurst, 1956).
Sweating was noted in only 8 per cent of our patients and in two patients it was the sole symptom.

\section{CONCLUSION}

In the elderly, myocardial infarction is but a phase in the course of coronary heart disease; multiple infarcts, old and new, infarction without thrombosis, and thrombosis with or without infarction, form a complex pattern. It is, therefore, understandable that the symptoms of infarction of the myocardium may range from the insignificant to the catastrophic.

The historical aspect of illness in the aged may be at best uncertain and on occasions misleading. It is subject to the vagaries of the memory. The mode of onset of cardiac infarction in old age is often ill defined and the presenting symptoms impossible to classify owing either to their multiplicity or to their vagueness. Advice may be sought because of the rapid deterioration in the state of health for no apparent reason; perhaps with insomnia or incontinence or anorexia with abdominal distension and often hiccups, or general apathy, or torpor.

Despite the disadvantages of a culled series of cases, it is thought that the classification used in this paper will stress the protean clinical manifestation of myocardial infarction.

\section{SUMMARY}

The presenting clinical features in 387 patients with myocardial infarction are described. Patients were aged 65 and over and were divided into 15 groups according to the dominating symptom. Only 19 per cent of the total had a "classical" onset, with substernal or epigastric pain or discomfort. The mode of presentation in 81 per cent was with dyspnœa, confusion, sudden death, syncope, stroke, giddiness, peripheral gangrene, palpitation, renal failure, recurrent vomiting, weakness, pulmonary embolus, restlessness, or sweating.

\section{REFERENCES}

Acheson, J., and Hutchinson, E. C. (1964). Observations on the natural history of transient cerebral ischæmia. Lancet, $2,871$.

Achor, R. W. P., Futch, W. D., Burchell, H. B., and Edwards, J. E. (1956). The fate of patients surviving acute myocardial infarction. A study of clinical and necropsy data in two hundred and fifty cases. Arch. intern. Med., 98, 162.

Allen, E. V., Barker, N. W., and Hines, E. A., Jr. (1962). Peripheral Vascular Diseases, 3rd ed. W. B. Saunders, Philadelphia and London.

Babey, A. M. (1939). Painless acute infarction of the heart. New Engl. F. Med., 220, 410. 
Barnes, A. R., and Ball, R. G. (1932). The incidence and situation of myocardial infarction in one thousand consecutive postmortem examinations. Amer. F. med. Sci., 183, 215.

Bean, W. B. (1937). Infarction of the heart. A morphological and clinical appraisal of 300 cases. Part 1 . Predisposing and precipitating conditions. Amer. Heart F., 14, 684.

- (1938). Infarction of the heart. III. Clinical course and morphological findings. Ann. intern. Med., 12, 71.

—, Flamm, G. W., and Sapadin, A. (1949). Hemiplegia attending acute myocardial infarction. Amer. F. Med., 7, 765.

manifestations in acute myocardial infarction. Amer. Heart F., 23, 362.

Bedford, D. E., and Simpson, K. (1939). Coronary thrombosis. Trans. med. Soc. Lond., 62, 165 and 177.

Boyd, L. J., and Werblow, S. C. (1937). Coronary thrombosis without pain. Amer. F. med. Sci., 194, 814.

Bruenn, H. G., Turner, K. B., and Levy, R. L. (1936), Notes on cardiac pain and coronary disease. Amer. Heart F., 11, 34.

Burch, G. E., Meyers, R., and Abildskov, J. A. (1954). A new electrocardiographic pattern observed in cerebrovascular accidents. Circulation, 9, 719.

Byer, E., Ashman, R., and Toth, L. A. (1947). Electrocardiograms with large, upright $\mathrm{T}$ waves and long $\mathrm{Q}-\mathrm{T}$ intervals. Amer. Heart f., 33, 796.

Carr, J. G. (1935). The symptoms and diagnosis of coronary occlusion. Illinois med. $\mathcal{F}$., 68, 155.

Carter, A. B. (1964). Cerebral Infarction. Pergamon Press, Oxford.

Conner, L. A., and Holt, E. (1930). The subsequent course and prognosis in coronary thrombosis; an analysis of 287 cases. Amer. Heart F., 5, 705.

Cookson, H. (1942). Fainting and fits in cardiac infarction. Brit. Heart f., 4, 163.

Cropp, G. J., and Manning, G. W. (1960). Electrocardiographic changes simulating myocardial ischemia and infarction associated with spontaneous intracranial hemorrhage. Circulation, 22, 25.

Davis, N. S. (1932). Coronary thrombosis without pain: its incidence and pathology. F. Amer. med. Ass., 98, 1806.

Dozzi, D. L. (1937). Cerebral embolism as a complication of coronary thrombosis. Amer. F. med. Sci., 194, 824.

East, C. F. T., Bain, C. W. C., and Cary, F. L. (1928). Cardiac infarction without pain. Lancet, 2, 60.

Ebert, R. V. (1965). Treatment of acute left ventricular failure. Modern Treatment, 2, 233. Harper and Row, New York.

Eppinger, E. C., and Kennedy, J. A. (1938). The cause of death in coronary thrombosis, with special reference to pulmonary embolism. Amer. F. med. Sci., 195, 104.

Evans, W. (1964). Diseases of the Heart and Arteries. E. and $S$. Livingstone, Edinburgh and London.

- , and Sutton, G. C. (1956). Painless cardiac infarction. Brit. Heart F., 18, 259.

Fagin, I. D., and Chapnick, H. A. (1950). Clinical patterns of myocardial infarction in ambulant patients. Ann. intern. Med., 32, 243.

Fentz, V., and Gormsen, J. (1962). Electrocardiographic patterns in patients with cerebrovascular accidents. Circulation, 25, 22

Fisch, C., Genovese, P. D., Dyke, R. W., Laramore, W., and Marvel, R. J. (1957). The electrocardiogram in persons over 70. Geriatrics, 12, 616.

Fisher, R. L., and Zukerman, M. (1946). Coronary thrombosis. F. Amer. med. Ass., 131, 385.
Friedberg, C. K. (1956). Diseases of the Heart, 2nd ed. W. B. Saunders, Philadelphia and London.

Gairdner, W. T. (1891). Medical Society of London. Adjourned discussion on angina pectoris. Lancet, 1, 604.

Gallavardin, L. (1921), Symptomes et diagnostic de l'infarctus du myocarde. $\mathcal{F}$. Méd. Lyon, $2,913$.

Garland, H. G., and Phillips, W. (1953). Medicine. Macmillan, London.

Gertler, M. M., White, P. D., Bland, E. F., Fertig, J., Garn, S. M., Lerman, J., Levine, S. A., Sprague, H. B., and Turner, N. C. (1954). Coronary Heart Disease in Young Adults. Harvard University Press, Cambridge, Massachusetts.

Gilchrist, A. R. (1951). Refresher course for general practitioners. Coronary artery disease- $\mathrm{I}$. The clinical syndromes. II. Treatment. Brit. med. F., 1, 874 and 937.

Gorham, L. W., and Martin, S. J. (1938). Coronary occlusion with and without pain. Arch. intern. Med., 62, 821.

Gould, S. E., and Cawley, L. P. (1958). Unsuspected healed myocardial infarction in patients dying in a general hospital. Arch. intern. Med., 101, 524.

Gross, H., and Engelberg, H. (1940). Essential hypertension. A comparison of the hypertensive and non-hypertensive phases following coronary thrombosis. Amer. $\mathcal{f}$. med. Sci., 199, 621.

Gupta, P. D., Bawa, Y. S., and Wahi, P. L. (1965). Cerebrovascular accidents. A clinical analysis of 260 cases. Indian Heart $\mathcal{F}$., 17, 57.

Hamman, L. (1926). Symptoms of coronary occlusion. Bull. Fohns Hopk. Hosp., 38, 273.

(1934). Remarks on the diagnosis of coronary occlusion. Ann. intern. Med., 8, 417.

Hammer, A. (1878). Ein Fall von thrombotischem Verschlusse einer der Kranzarterien des Herzens. Wien. med. Wschr., 28, 97.

Harrison, M. T., and Gibb, B. H. (1964). Electrocardiographic changes associated with a cerebrovascular accident. Lancet, 2, 429.

Hay, J. (1933). Certain aspects of coronary thrombosis. Lancet, 2, 787.

Hellerstein, H. K., and Martin, J. W. (1947). Incidence of thrombo-embolic lesions accompanying myocardial infarction. Amer. Heart F., 33, 443.

Heron, J. R., and Anderson, E. G. (1965). Concomitant cerebral and cardiac ischæmia. Lancet, 2, 405.

$\longrightarrow,-$, and Noble, I. M. (1965). Cardiac abnormalities associated with carotid-sinus syndrome. Lancet, $2,214$.

Herrick, J. B. (1912). Clinical features of sudden obstruction of the coronary arteries. F. Amer. med. Ass., 59, 2015. (1931). Coronary artery in health and disease (Harvey lecture). Amer. Heart f., 6, 589.

Herrman, G. R. (1952). Diseases of the Heart and Arteries, 4th ed. Henry Kimpton, London.

Howard, T. (1934). Coronary occlusion: based on the study of 165 cases. Med. Tms and Long Island med. F., 62, 337.

Jacobs, A. L. (1959). Arterial Embolism in the Limbs. E. \& S. Livingstone, Edinburgh and London.

Keefer, C. S., and Resnik, W. H. (1928). Angina pectoris. Syndrome caused by anoxemia of the myocardium. Arch. intern. Med., 41, 769.

Kennedy, J. A. (1937). The incidence of myocardial infarction without pain in two hundred autopsied cases. Amer. Heart F., 14, 703.

Koskelo, P., Punsar, S., and Sipilä, W. (1964). Subendocardial hæmorrhage and E.C.G. changes in intracranial bleeding. Brit. med. F., 1, 1479. 
Levine, H. D. (1953). Non-specificity of the electrocardiogram associated with coronary artery disease. Amer. $\mathcal{F}$. Med., 15, 344.

Levine, S. A. (1929). Coronary Thrombosis. Williams \& Wilkins, Baltimore.

- (1958). Clinical Heart Disease, 5th ed. W. B. Saunders, Philadelphia and London.

—, and Brown, C. L. (1929). Coronary thrombosis: its various clinical features. Medicine (Baltimore), 8, 245.

Lewis, T. (1946). Diseases of the Heart, 4th ed. Macmillan, London.

- , and Pickering, G. W. (1934). Observations upon maladies in which the blood supply to digits ceases intermittently or permanently, and upon bilateral gangrene of digits; observations relevant to so-called "Raynaud's disease". Clin. Sci., 1, 327.

Leyden, E. (1884). Utber die Sclerose der Coronar-Arterien und die davon abhängigen Krankheitszustände. $Z$. klin. Med., 7, 459.

Libman, E. (1919). Some observations on thrombosis of the coronary arteries (Abstract). Trans. Ass. Amer. Phycns, 34, 138.

Logue, R. B., and Hurst, J. W. (1956). Coronary atherosclerosis. In The Practice of Medicine, by J. C. Meakins, 6th ed., Section XI, p. 968. Mosby, St. Louis.

Mallory, G. K., White, P. D., and Salcedo-Salgar, J. (1939). The speed of healing of myocardial infarction. A study of the pathologic anatomy in seventy-two cases. Amer. Heart f., 18, 647.

Master, A. M., Dack, S., and Jaffe, H. L. (1938). Postoperative coronary artery occlusion. $\mathcal{F}$. Amer. med. Ass., 110, 1415.

Meakins, J. C., and Eakin, W. W. (1932). Coronary thrombosis: a clinical and pathological study. Canad. med. Ass. F., 26, 18.

Menon, I. S. (1964). Electrocardiographic changes simulating myocardial infarction in cerebrovascular accident. Lancet, 2, 433.

Miller, J. H., McDonald, R. K., and Shock, N. W. (1952). Age changes in the maximal rate of renal tubular reabsorption of glucose. F. Geront., 7, 196.

Mitchell, J. R. A., and Schwartz, C. J. (1963). The relation between myocardial lesions and coronary artery disease. II. A selected group of patients with massive cardiac necrosis or scarring. Brit. Heart f., 25, 1.

Obrastzow, W. P., and Straschesko, N. D. (1910). Zur Kenntnis der Thrombose der Koronararterien des Herzens. Z. klin. Med., 71, 116.

Olbrich, O., Ferguson, M. H., Robson, J. S., and Stewart, C. P. (1950). Renal function in aged subjects. Edinb. med. F., 57, 117.

Papp, C. (1952). Acute cardiac infarction without pain. Brit. Heart F., 14, 250.

Parkinson, J., and Bedford, D. E. (1928). Cardiac infarction and coronary thrombosis. Lancet, $1,4$.

Parry, C. H. (1799). An Inquiry into the Symptoms and Causes of the Syncope Anginosa Commonly Called Angina Pectoris. Cruttwel, Bath; Cadell and Davies, London.

Pathy, M. S. (1963). Clinical features of myocardial infarction in the elderly. Sixth International Congress of Gerontology, Copenhagen.
Pollard, H. M., and Harvill, T. H. (1940). Painless myocardial infarction. Amer. F. med. Sci., 199, 628.

Pomerance, A. (1965). Pathology of the heart with and without cardiac failure in the aged. Brit. Heart f., 27, 697.

Race, G. A., and Lisa, J. R. (1945). Combined acute vascular lesions of brain and heart: a clinical-pathologic study of fifteen cases. Amer. F. med. Sci., 210, 732.

Rodstein, M. (1956). The characteristics of nonfatal myocardial infarction in the aged. Arch. intern. Med., 98, 84.

Rogers, F. B. (1955). Unsuspected cardiac infarction with cerebrovascular accidents. F. Amer. Geriat. Soc., 3, 714.

Rose, G. A., and Wilson, R. R. (1959). Unexplained heart failure in the aged. Brit. Heart f., 21, 511.

Roseman, M. D. (1954). Painless myocardial infarction: a review of the literature and analysis of two-hundred and twenty cases. Ann. intern. Med., 41, 1.

Saphir, O., Priest, W. S., Hamburger, W. W., and Katz, L. N. (1935). Coronary arteriosclerosis, coronary thrombosis, and resulting myocardial changes: an evaluation of their respective clinical pictures including the electrocardiographic records, based on the anatomical findings. Amer. Heart F., 10, 567 and 762.

Shock, N. W. (1946). Kidney function tests in aged males. Geriatrics, 1, 232.

- (1952). Age changes in renal function. In Cowdry's Problems of Ageing, 3rd ed., p. 614. Williams \& Wilkins, Baltimore.

Shuster, S. (1960). The electrocardiogram in subarachnoid hæmorrhage. Brit. Heart f., 22, 316.

Snow, P. J. D., Jones, A. Morgan, and Daber, K. S. (1956). A clinico-pathological study of coronary disease. Brit. Heart F., 18, 435.

Srivastava, S. C., and Robson, A. O. (1964). Electrocardiographic abnormalities associated with subarachnoid hæmorrhage. Lancet, 2, 431.

Stürup, H. (1952). Coronary thrombosis and other forms of circulatory insufficiency coinciding with cerebral apoplexy. Acta med. scand., 144, 189.

Warner, H. R. (1951). "Painless" myocardial infarction. Minn. Med., 34, 49.

Wasserman, F. Choquette, G., Cassinelli, R., and Bellet, S. (1956). Electrocardiographic observations in patients with cerebrovascular accidents. Amer. F. med. Sci., 231, 502.

Wearn, J. T. (1923). Thrombosis of the coronary arteries, with infarction of the heart. Amer. F. med. Sci., 165, 250.

White, P. D. (1951). Heart Disease, 4th ed. Macmillan, New York.

Wilson, G., Rupp, C., Jr., Riggs, H. E., and Wilson, W. W. (1951). Factors influencing the development of cerebral vascular accidents. I. Role of cardiocirculatory insufficiency. F. Amer. med. Ass., 145, 1227.

Wood, P. (1956). Diseases of the Heart and Circulation, 2nd ed. Eyre and Spottiswoode, London.

Wright, I. S., Marple, C. D., and Beck, D. F. (1954). Myocardial Infarction: Its Clinical Manifestations and Treatment with Anticoagulants. Grune and Stratton, New York. 